\title{
Pribumi di Mata Kolonial dalam Kumpulan Cerpen Teh dan Pengkhianat Karya Iksaka Banu
}

\section{Indigenous People in the Eyes of Colonialists in Iksaka Banu's Collection of Short Stories entitled Teh dan Penghianat}

\author{
Mega Widyawatia ${ }^{2}$ Eggy Fajar Andalas ${ }^{b}$

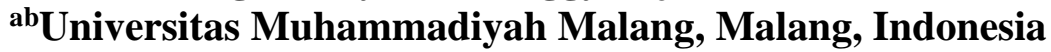

Pos-el:megawdwt98@gmail.com;eggy@umm.ac.id

\section{Naskah Diterima Tanggal 18 Februari 2021—Direvisi Akhir Tanggal. 05 Desember 2021.—Disetujui Tanggal 10 Desember 2021}

\begin{abstract}
Abstrak
Penelitian ini bertujuan untuk membahas aspek sosial dan budaya yang melekat dengan sejarah Indonesia mengenai peristiwa penjajahan bangsa Belanda pada kumpulan cerpen yang berjudul Teh dan Pengkhianat menggunakan kajian new historicism. Teori yang digunakan untuk menganalisis relevansi karya sastra sebagai dokumen sosial adalah new historicism dari Stephen Greenblatt (1980). Sementara itu, teori yang digunakan untuk menganalisis sudut pandang kolonial Belanda mengenai pribumi adalah orientalisme dari Edward Said (1935). Hasil analisis yang ditemukan adalah sebagai berikut. Pertama, representasi sejarah ditandai dengan ketakutan, pengendalian, paksaan, kekuatan melawan oleh pribumi pada masa kolonial sebelum dan sesudah tahun 1945. Kedua, representasi sosial ditandai dengan kemanusiaan, persiapan, dan kegigihan dalam menghadapi virus variola yang terjadi pada tahun 1644. Ketiga, representasi budaya ditandai dengan kerja keras pribumi atas persamaan hak dalam gaya berpakaian hingga transportasi. Data-data yang menunjukkan kerja keras di antaranya adalah eksistensi (ruang, proses, dan objek), identitas (sepadan), kesatuan/multiplitas (penggabungan) antara pribumi dan kolonial.
\end{abstract}

Kata-kata kunci: new historicism, orientalisme, cerita pendek, kolonial

\section{Abstract}

This research aims to discuss social and cultural aspects that are closely related to Indonesian history regarding events of colonialism in the collection of short stories entitled Teh dan Pengkhianat by applying new historicism. This is a descriptive qualitative research. The theory used to analyze the relevance of literary works as social documents is from new historicism, Stephen Greenblatt (1980). Besides, the theory used to investigate colonialist perspectives on indigenous peoples is form orientalism, Edward Said (1935). The results of this research are as follows. First, historical representations are marked by fear, restraint, compulsion, and counterforce of indigenous people in the colonial period before and after 1945. Second, social representation is marked by humanity, preparation, and persistence in dealing with the variola virus that occurred in 1644. Third, cultural representations are marked by the hard work of indigenous people for equal rights in clothing style until transportation. Data that demonstrates hard work is the existence (space, process, and object), identity (matching), and unity/multiplicity (merging) of indigenous peoples and colonialists.

Keywords: new historicism, orientalism, the short story, colonialists 


\section{PENDAHULUAN}

Sejarah perjalanan kehidupan sebuah bangsa sering menjadi inspirasi pengarang dalam proses penciptaan karya sastra (Dewi, 2015; Wellek dan Warren, 2014; Yunan, 2015). Kolonialisme yang terjadi di Indonesia, setidaknya kolonialisme Belanda tercatat lebih dari 350 tahun (Kirom, 2020), merupakan bahan baku yang tidak pernah habis dibahas dalam beragam sisi. Berbagai dinamika yang terjadi dalam beragam aspek kehidupan bangsa Indonesia menjadi inspirasi bagi pengarang pascakolonial dalam menggambarkan peristiwa tersebut dalam bentuk karya sastra.

Sejarah dan sastra memiliki hubungan yang selaras pada mekanisme interpretatifnya. Rentang kisah yang jauh antara masa lalu dan sekarang menjadikan realitas objektif pada sejarah sulit untuk diketahui kebenarannya sehingga sejarawan hanya mampu merekonstruksi peristiwa masa lalu berdasarkan buktibukti yang ditemukan (Haryadi, 2013; Sahliyah, 2017). Di sisi lain, kisah sejarah sering direkonstruksi kembali melalui interpretasi pengarang terhadap suatu peristiwa. Mekanisme interpretatif yang dilakukan bisa bersifat subjektif ataupun objektif. Di Indonesia sangat banyak ditemui karya sastra yang menjadikan peristiwa sejarah sebagai dasar pengembangan cerita dalam karyakaryanya.

Salah satu karya sastra yang menggunakan latar belakang sejarah adalah kumpulan cerpen (kumcer) Teh dan Pengkhianat karya Iksaka Banu (2019). Karya ini mengangkat beberapa peristiwa sejarah yang terjadi pada masa kolonial dan pascakolonial yang kemudian dikembangkan sesuai dengan imajinasi pengarang. Keseluruhan isi kumcer mengambil sudut pandang yang sedikit berbeda dengan catatan sejarah, yakni interpretasi bahwa bangsa Belanda yang hidup di Hindia Belanda tidak seluruhnya kejam. Pengarang mengambil sudut pandang yang berbeda dengan stigma yang ada di masyarakat mengenai orang Belanda pada masa kolonialisme (Ikbar dan Andalas, 2019; Yasa, 2013).

Jika mengacu pada historiografi Indonesia, tercatat dalam sejarah bangsa Indonesia bahwa Belanda datang ke Indonesia (1596) dan mendirikan kongsi dagang VOC (1602) sebagai upaya meningkatkan perekonomian karena persaingan antarnegara di Eropa (Absiroh, Isjoni, dan Bunari, 2017). Kepentingan ekonomi inilah yang menjadikan adanya monopoli perdagangan, ekploitasi alam, dan perbudakan masyarakat pribumi. Dalam perspektif historiografi Indosentris, bangsa kolonial dianggap sebagai penjajah yang kejam karena perilaku penindasan yang mereka lalukan terhadap wilayah jajahan. Hal ini dipengaruhi oleh stratifikasi kelas sosial yang berujung pada tindak rasisme mampu menciptakan perpecahan di antara dua belah pihak, yakni penjajah dan pribumi (Yasa, 2013:251). Pandangan ini tentu akan berbeda dari perspektif Neerlandosentris yang melihat meskipun terjadi kekejaman yang tidak manusiawi, seperti perbudakan, perampasan, dan pembunuhan masyarakat pribumi, tetapi itu tidak dilakukan oleh seluruh orang Belanda yang ada di Indonesia pada masa itu. Gambaran ini seperti yang diperlihatkan oleh Eduard Douwes Dekker atau Multatuli dalam 
karyanya Max Havelaar yang diterbitkan pertama kali pada 1860 (Multatuli, 2016).

Perbedaan cara pandang inilah yang ditemukan dalam kumcer Teh dan Pengkhianat. Pengarang seolah-olah meletakkan posisi pribumi sebagai pribadi yang memiliki sisi negatif, di posisi yang lain ia meletakkan beberapa bangsa Belanda memiliki sisi kemanusiaan. Hal ini tentu bertolak belakang dengan catatan sejarah dan pandangan masyarakat terhadap pihak kolonial yang identik dengan kekejaman, kekerasan, dan ketidakadilan.

Kumcer ini mengambil konteks yang berbeda dengan historiografi tertulis yang ada dan tidak mengurangi konteks umum, yaitu menitikberatkan tokoh seorang Belanda berkulit putih, baik Belanda totok maupun mestizo. Latar belakang kumcer ini sebagian besar pada masa kolonial, lebih tepatnya sangat jauh dari kemerdekaan, sedang yang lain pada masa sebelum atau sesudah proklamasi.

Salah satu sisi kemanusiaan yang diceritakan dalam cerpen, seperti tokoh Hendriek Cornelis Adam dalam cerpen Kalabaka yang melindungi pribumi atas kekejaman penguasa pada masa VOC, tokoh Dr. Jan Veldhart dalam cerpen Variola yang menyelamatkan pribumi yang terjangkit penyakit cacar ganasisu. Sementara itu, sisi gelap pribumi diceritakan dalam cerpen Teh dan Pengkhianat yang menggambarkan pribumi yang berkhianat dan membunuh sesama pribumi lainnya. Cerpen-cerpen yang lain juga masih memiliki tanda yang sama, yakni interpretasi kemanusiaan kolonial yang membela pribumi atas kekejaman penguasa dan interpretasi yang menunjukkan beberapa sisi negatif pihak pribumi.

Realitas tekstual yang tergambar dalam karya ini sangat menarik untuk diteliti. Penelitian ini bertujuan mendeskripsikan perspektif pribumi dalam sudut pandang kolonial yang tergambarkan dalam kumcer Teh dan Pengkhianat karya Iksaka Banu (2019). Berdasarkan penelusuran peneliti, penelitian terhadap permasalahan yang dijabarkan belum pernah dilakukan peneliti sebelumnya. Adapun penelitian yang telah dilakukan berfokus pada permasalahan hibriditas dan ambivalensi tokoh dalam cerita (Maharani, Suhendi, dan Ansori, 2020), jejak kolonialisme (Al Kautsar, 2020), resistensi ideologis (Sari, 2021), unsur sejarah dan nilai pendidikan (Oktiva dan Syamsudin, 2021), dan hibriditas tokoh utama (Aromah, 2021). Oleh karena itu, penelitian ini penting dilakukan untuk memberikan sudut pandang berbeda, utamanya salah satu perspektif penulis Indonesia terhadap posisi Belanda pada masa kolonialisme atuapun pascakolonialisme di Indonesia.

Dalam penelitian ini digunakan perspektif new historicism. Kajian ini mempertimbangkan relevansi karya sastra sebagai dokumen sosial, sedangkan imajinasi pengarang dalam karya sastra digunakan untuk mewakili refleksi pada zamannya (Ardhianti, 2016:2). New historicism mengkaji karya sastra tidak hanya melihat karya sastra secara utuh, melainkan juga teori yang menyandingkan teks nonsastra dengan teks sastra. Sejarah, melalui kajian new historicism, dilihat melalui peristiwa masa lalu yang ditemukan di dalam karya sastra kemudian disandingkan dengan teks nonsastra 
sebagai acuan. Sejarah sebagai acuan karya sastra bukan sekadar latar belakang, tetapi turut menyusun satu kisah tentang kenyataan. Jadi, antara karya sastra dan sejarah memiliki jalinan hubungan antara teks sastra maupun teks nonsastra (fakta) yang diproduksi pada kurun waktu yang sama ataupun berbeda (Purnamasari, 2019).

Secara khusus kajian new historicism mencoba mendalami kembali konstruksi kekuasaan beserta komponen yang dibentuknya melalui pembacaan secara memadai berdasarkan teks yang ada. Teks itu kemudian dieksplisitkan kembali dalam rangka menyingkap praktik perbedaan penalaran yang berkembang dan beroperasi di dalam isinya (Wibowo, 2018). Dalam kaitannya dengan penelitian di Indonesia, hal ini belum banyak dilakukan selain pandangan terhadap sejarah masih umum. Artinya, teks lain yang juga mengungkapkan sejarah secara lebih benderang diabaikan karena dianggap fiksi. Selama ini sejarah masih dipandang dari kacamata penguasa (Rahayu, 2017). Dari kacamata pihak terbuang, sejarah tersebut acap kali diabaikan. Oleh karena itu, dalam konteks kajian new historicism teks menduduki posisi penting untuk membedah basis kekuasaan yang ada dengan mengambil dari sudut pandang yang berbeda dari kebanyakan. New historicism bukanlah sebuah doktrin, melainkan model kerja. Sistem pada penelitian ini berkutat pada masa lalu dan sumber datanya dari dokumen historis atau nonhistoris (karya sastra) dan sumber tertulis atau nontertulis (gambar) sebagai sumber yang sama-sama penting. Oleh karena itu, kajian new historicism lebih dikenal sebagai bagian dari kajian budaya.

Selain new historicism, penelitian ini juga meminjam konsep orientalisme yang dikemukakan oleh Edward Said untuk memahami orang Timur (pribumi) berdasarkan tempatnya yang khusus dalam pengalaman dan sudut pandang orang Barat (Said, 2001). Bagi koloni, pribumi bukan hanya dekat secara fisik dan relasi, melainkan suatu hasil kolonialisme Eropa yang terbesar, terkaya, dan tertua. Oleh karenanya, pribumi bukanlah sebuah ilusi dan imajinasi dalam karya sastra semata, tetapi juga bagian dari sejarah tertulis dari pengalaman, kepribadian, peradaban, dan kebudayaan yang dianggap sebagai suatu kebalikan dari koloni bangsa Eropa.

\section{KAJIAN TEORI}

\section{New Historicism}

Kajian new historicism pertama kali diperkenalkan oleh Stephen Greenblatt, seorang sejarawan sastra asal Amerika Serikat. Greenblatt memberikan perspektif baru dalam kajian renaisans melalui bukunya yang berjudul Renaissans Self-Fashioning: From More to Shakespeare (1980), yaitu sebuah kajian yang menekankan hubungan teks sastra dengan berbagai konteks masyarakat seperti kekuatan sosial, ekonomi, dan politik. Realita dalam imajinasi sastra tersebut justru dapat bertolak belakang dengan realita yang disuguhkan dalam sejarah masyarakat sesungguhnya sehingga menjadi sebuah paradoks dengan harapan akan ada perkembangan suatu realita lain yang lebih baik (Fathoni, 2013).

Greenblatt memandang bahwa kecenderungan kajian tekstual dalam teori kritisme sastra dapat bersifat ahistoris 
(Ardhianti, 2016). Hal ini dikarenakan sastra berada pada wilayah estetik otonom dan terpisah dari komponen-komponen di luar karya sastra sehingga kisah sejarah yang tidak tertulis dapat dijadikan sebagai media kritisme.

New historicism mengacu pada dua hal penting sebagai dasar, yaitu (1) memahami sastra melalui sejarah dan (2) memahami budaya, sejarah, dan pemikiran melalui sastra. Oleh karena itu, pada kajian new historicism tidak ada perbedaan antara teks sastra dengan nonsastra.

Menurut Artika (2015), kajian new historicism berguna dalam memaknai karya sastra dalam kerangka hubungan dengan teks nonsastra karena argumen tentang makna teks sastra mudah diuraikan dengan hanya melihat pada catatan sejarah. Sejarah seperti pisau analisis yang kuat karena acap kali memberikan dasar yang kokoh untuk memancangkan pernyataan yang berkenaan dengan makna. Kajian ini (Barry, 2010:202) juga memandang bahwa sastra bukan sebagai cerminan transparan dan pasif sejarah, melainkan ikut membangun, mengartikulasikan, dan mereproduksi konvensi, norma, nilai budaya melalui tindak verbal dan imajinatif kreatif.

\section{Orientalisme}

Orientalisme merupakan suatu cara membuat klaim-klaim untuk melegitimasi prasangka dan upaya dalam menundukkan Timur dengan memvisualisasikan dan menitikberatkan pada ambisi geografis pada dunia Timur (Said, 2001). Secara konservatif mereka memikirkan langkahlangkah dalam mempelajari perihal-perihal yang melekat pada dunia ketimuran. Latar belakang pengkajian orientalisme lebih kompleks (Teng, 2016).

Menurut Said (2001) ada tiga faktor penting yang melatarbelakangi orientalisme, yaitu (1) seorang orientalis adalah para ilmuwan barat yang mengajarkan, menulis, atau meneliti Timur dengan mengklaim bahwa dirinya memiliki pengetahuan dan memahami kepentingan-kepentingan Timur; (2) pemikiran yang berlandaskan pada pembedaan ontologis dan epistemologis yang diperuntukkan antara "the Orient" dan "the Occident"; (3) pendekatan orientalisme dapat didiskusikan dan dianalisis dalam menghadapi Timur, membuat pernyataan tentang Timur, membenarkan pandangan-pandangan tentang Timur dengan tujuan untuk menguasainya. Singkatnya, orientalisme ialah cara yang dilakukan oleh Barat untuk mendominasi, merestrukturasi, dan menguasai Timur.

Menurut Wibisono, Tjahjo, dan Wahjudianta (2017), pada intinya orientalisme ialah sebuah pembenaran imperialisme yang memandang budaya Timur belum berkembang dan belum sebanding dengan budaya Barat yang dianggap superior. Oleh karenanya, bangsa Barat mulai membentuk koloni mereka di negara lain lebih tepatnya di dunia Timur dengan tujuan pembenaran dan melakukan dominasi atas negara-negara lain tersebut.

\section{METODE PENELITIAN}

Penelitian ini berjenis kualitatif karena memahami fenomena dalam teks sastra dengan menggunakan data verbal (Sugiarti, Andalas, dan Setiawan, 2020). Sumber data penelitian adalah Kumcer Teh dan Pengkhianat karya Iksaka Banu. 
Kumcer tersebut diterbitkan oleh Kepustakaan Populer Gramedia (KPG), cetakan pertama, April 2019, dengan ketebalan 164 halaman dan terdiri atas 13 cerita pendek. Adapun data penelitian berupa kutipan-kutipan, kata-kata, dan kalimat-kalimat yang menunjukkan tentang sejarah pada era kolonial, kemanusiaan, serta ketidakadilan pribumi atas Belanda yang terdapat dalam kumcer Teh dan Pengkhianat. Selain itu, sumber data pendukung berupa buku-buku yang relevan dengan topik kajian, seperti bukubuku sejarah dan jurnal-jurnal ilmiah historis yang berkaitan dengan kajian.

Teknik pengumpulan data memakai teknik baca-catat. Teknik pengumpulan data dilakukan dengan membaca kumcer Teh dan Pengkhianat secara berulangulang dan detail untuk menelusuri peristiwa yang terjadi sebagai data penelitian. Kemudian, data-data yang diperoleh dicatat dan ditandai berdasarkan klasifikasi untuk digunakan sebagai bukti penegas dalam menganalisis data sesuai dengan tujuan kajian. Analisis teks sastra bertujuan menelusuri seluruh peristiwa yang terdapat dalam kumcer Teh dan Pengkhianat, kemudian disandingkan dengan sejarah tertulis. Teknik analisis data dalam penelitian melalui dua langkah: (1) melakukan analisis data meliputi penyajian data dan pembahasan berdasarkan dengan tujuan kajian, (2) menyimpulkan hasil analisis data mengenai interpretasi histori era kolonial, aspek kemanusiaan dan ketidakadilan melalui perspektif Belanda dalam kumcer Teh dan Pengkhianat.

\section{PEMBAHASAN}

Kumcer Teh dan Pengkhianat yang terdiri atas 13 cerita, mengangkat cerita pada era kolonial dengan mengambil dari sudut pandang orang Belanda. Latar tempat cerita berada di wilayah Hindia Belanda, sedangkan latar waktu dalam Teh dan Pengkhianat sepuluh cerita diambil sebelum kemerdekaan, di antaranya "Kalabaka", "Tegak Dunia", "Teh dan Pengkhianat", "Variola", "Sebutir Peluru Saja", "Lazarus Tak Ada di Sini", "Kutukan Lara Ireng", "Di Atas Kereta Angin", "Belenggu Emas", "Nieke de Flinder", "Tawanan", sedangkan tiga cerita yang lain latar waktu sesudah kemerdekaan, yakni "Tawanan", "Indonesia Memanggil", dan "Semua Sudah Selesai." Dari ketiga belas judul, enam judul berbicara mengenai orangorang pribumi dalam perspektif Belanda sekaligus menggali fenomena dari sisi sejarah yang lainnya, yang tidak hanya hitam di atas putih, melainkan akan ditemukan beberapa warna yang lain ketika cerita itu dilihat dari segala arah sudut pandang. Dari 13 judul cerpen hanya 6 yang digunakan karena banyak menginterpretasikan sejarah era kolonial pada tahun 1621 hingga 1949 melalui pikiran, tindakan, dan dialog antartokoh, sedangkan sisanya tidak digunakan karena kurangnya bukti-bukti fakta sejarah.

\section{Membedah Sisi Kemanusiaan Bangsa Belanda Terhadap Pribumi}

Kolonial Belanda memiliki peran besar dalam memosisikan pribumi yang terjajah sebagai masyarakat kelas ketiga. Secara tidak langsung, sikap kolonial Belanda menjadikan pengelompokan tersebut berdasarkan kepentingan politis 
serta kepentingan ideologis (Mandiri, 2015).

Dari Kalabaka berbicara mengenai
kebencian Belanda totok terhadap
penguasa VOC Belanda sehingga
memunculkan simpati orang Belanda
tersebut kepada pribumi. Melalui Hendriek
Cornelis Adam, mantan schutterij yang
merangkap sebagai seorang juru tulis dan asisten pribadi Tuan Nicolas van Waert dalam sebuah ekspedisi ke Pulau Banda. Adam menyaksikan betapa kejinya VOC membalas dendam dan melumpuhkan penduduk lokal dengan pembunuhan massal secara biadab. Belanda totok itu melihat kejadian keji tersebut secara langsung. Adam mengambil sikap berseberangan dengan pihak berkuasa saat itu dengan melawan dan menegakkan keadilan dalam secuil kisah pembantaian keji itu. Namun, nahas, Adam harus menerima eksekusi mati karena dinilai melawan penguasa. Hal itu terinterpretasi dalam kutipan berikut.

Ia Kalabaka. Anak muda terpelajar yang beberapa hari lalu menghabiskan senja di Naira bersamaku membicarakan sejarah dan kebudayaan negerinya. Kini, ia terpuruk menghadapi maut dengan cara mengerikan di tangan orang Eropa yang mengaku memiliki peradaban tinggi. Alangkah anehnya hidup ini (Banu, 2019).

Wujud kekejaman ini menurut wacana kolonial yang dipelopori oleh Said menggunakan ideologi teori kritis Foucault dalam rangka untuk mengungkapkan narsisme dan kekerasan epistemologi Koloni Barat terhadap Pribumi Timur dengan tendensius dan berpihak pada kepentingan penguasa seperti yang terkandung dalam berbagai teori yang dikemukakan oleh kaum kolonialis dan orientalis (Baso, 2005:209-210). Tendensius dan kekuasaan yang ditunjukkan dalam kumcer tersebut ditunjukkan oleh kaum penguasa terhadap pribumi dengan tindak kekejamannya. Kemudian, Adam digambarkan sebagai pihak Belanda yang menanggapi dengan kritis pada perlakuan tidak benar seperti kejahatan antarmanusia. Ketidaksetujuannya atas sikap penguasa yang semena-mena terlihat jelas. Tindakan penguasa penjajah Belanda yang menerapkan sistem diskriminasi telah memosisikannya sebagai superior di atas pribumi (Hardiningtyas, 2018).

Hal demikian sesuai dengan pandangan Said yang menyatakan bahwa segala hal yang bercorak "Timur" dalam istilah orientalnya merujuk pada orang yang diorientkan sebagai individu yang lemah dan tak berdaya atas penguasa sehingga apabila mempunyai daya dan kekuatan maka akan dianggap membahayakan pihak kolonial. Berdasarkan sudut pandang Belanda pada kutipan yang disajikan, jelas memperlihatkan bagaimana kaum Barat memperlihatkan sisi bahwa bangsa Belanda yang sedari dahulu dianggap sebagai contoh bangsa Timur, tetapi berlaku kejam (Said, 2010). Namun, di sisi yang lain pihak Belanda yang lain juga memperlihatkan sisi ketidaksetujuan terhadap penguasa. Hal tersebut menjadi sebuah interpretasi bahwa bangsa Belanda dari pihak yang menyatakan dirinya sebagai penguasa tidak konsisten dengan hal-hal yang telah mereka agung-agungkan sebagai contoh dan teladan bangsa "Timur". Kekejaman dan ketidakadilan 
jelas menggambarkan bahwa mereka melampaui batas dari sisi kemanusiaan, bahkan dari sisi keagungan. Namun, tidak baik menyamaratakan perspektif tersebut karena pada kenyataannya ada beberapa orang Belanda yang melawan bangsanya sendiri.

Dalam praktiknya, diskriminasi penguasa penjajah terhadap kaum jajahannya disertai dengan penghinaan, pemerkosaan hak asasi, perampasan atas hak milik pribumi, dan pembedaan perlakuan hukum yang keseluruhannya selalu bertentangan dengan kemanusiaan, kemerdekaan individu, dan keadilan (Rusdian, 2017). Dengan demikian, kolonial Belanda memiliki peran besar dalam memosisikan pribumi sebagai masyarakat kelas bawah.

$$
\text { Penggalian kisah Kalabaka, }
$$

ditemukan bahwa Hendriek Cornelis Adam bergegas menghampiri Gubernur Snock dengan mengayunkan kepalan tangan hingga sang penguasa tersebut terjengkang. Akibat tindakannya tersebut, Adam harus membayar dengan nyawanya sendiri. Kutipan berikut sebagai bukti bahwa bangsa Barat tidak konsisten pada motonya sebagai pihak teladan.

Bangkitlah menjadi pria pemberani di hadapan kebenaran. Buatlah dunia Barat yang pongah ini mengerti, betapa berdosa merampas hak hidup seseorang. Apalagi suatu bangsa (Banu, 2019).

Kutipan tersebut menjadi penutup cerita Kalabaka, dari Adam yang ditujukan kepada anaknya, bahwa bangsa Barat dengan segala argumen yang telah terbentuk mengaku sebagai teladan bangsa Timur, tidaklah harus diteruskan. Adam menginginkan anaknya untuk dapat mengubah pendapat pada masa depan tersebut supaya membela kebenaran untuk melawan ketidakadilan.

Sisi kemanusiaan Belanda juga ditunjukkan melalui Variola, yang berbicara mengenai penyakit cacar mematikan yang telah menyebar di beberapa wilayah Hindia Belanda. Penyakit cacar diyakini telah menyebar ke wilayah Jawa sejak tahun 1644. Selanjutnya, diketahui penyakit ini mulai menyebar ke beberapa wilayah di Jawa maupun luar Jawa (Baha'uddin, 2016). John Crawfurd, dokter kebangsaan Inggris yang datang bersama dengan Raffles, telah mencatat bahwa pernah terjadi wabah virus penyakit cacar yang menimbulkan kekacauan yang luar biasa di antara penduduk pribumi (Boomgard, 1987).

Sejarah mengenai penyakit cacar yang terjadi di Hindia Belanda digambarkan melalui kisah Variola. Penyejajaran kedua bukti kajian yakni sejarah dan karya sastra, sejalan dengan kajian new historicism. Variola bercerita mengenai dr. Jan Veldhart yang memperjuangkan untuk menemukan cara cepat dalam menyelamatkan masyarakat pribumi yang terjangkit virus cacar. Jan Veldhart diinterpretasikan sebagai Belanda totok yang tidak memihak siapa pun, bahkan kepada penguasa. Jan Veldhart berusaha untuk membela yang menurutnya perlu dibela. Hal tersebut berkaitan dengan tugasnya sebagai seorang dokter, yakni memberikan obat kepada orang-orang yang membutuhkan, tanpa pilih kasih.

Dalam sejarah tercatat bahwa pemberian vaksin telah ditentang oleh banyak orang (Wisnuwardana, 2016:12). Alasan yang pertama, pejabat pemerintah lokal dan para ulama menentang adanya 
kebijakan vaksinasi cacar karena dianggap sebagai penolakan terhadap takdir Tuhan. Alasan yang kedua, kebijakan vaksinasi cacar bagi penduduk pribumi yang belum yakin tentang manfaat vaksinasi karena masih sering terjadi anak-anak yang sudah divaksinasi masih juga tertular cacar, bahkan ada yang meninggal karena penyakit yang sama. Namun, alasan yang logis adalah alasan yang kedua sehingga irasionalnya alasan yang lain terekam dalam kutipan percakapan seorang pendeta dengan dokter Belanda berikut.

"Tuan akan mengambil darah anak-anak kulit putih untuk dicampurkan, bahkan dimasukkan ke dalam tubuh para bumiputra. Dan dikesempatan lain Tuan melakukan sebaliknya. Betul? Apakah Tuan lupa, kita harus menjunjung tinggi kemurnian dan kekudusan tubuh ciptaan Tuhan?"

"Ini keadaan darurat. Saya bisa menunjukkan nama-nama pemuka agama yang mendukung upaya serius mencegah wabah mematikan ini." (Banu, 2019).

Dalam Variola, dr. Jan Veldhart berupaya menanggulangi penyakit cacar melalui inokulasi. Dalam cerita, gagasan inokulasi pernah dilakukan karena polanya sama dengan para gadis pemerah susu di Eropa yang terjangkit penyakit cacar sapi, ternyata kebal terhadap serangan cacar manusia.

Sebagaimana yang terjadi di Eropa atau kawasan lain, tindakan yang digunakan sebagai upaya penanggulangan terhadap penyakit cacar pada abad ke-18 di Indonesia adalah variolasi. Seiring dengan ditemukannya vaksin cacar pada akhir abad ke-18, pada awal abad ke-19 vaksinasi cacar mulai digunakan di
Indonesia sebagai upaya pengendalian penyakit cacar. Pada tahun 1779 , seorang dokter muda Belanda bernama J. Van der Steege melakukan percobaan pertama variolasi di Batavia. Steege melakukan inokulasi terhadap 13 orang yang terkena cacar, beberapa di antaranya adalah dari kelompok anak-anak. Percobaan variolasi pertama ini mendapatkan hasil yang baik (Wisnuwardana, 2016).

Persamaan antara kedua cerita, yakni dari sisi sejarah maupun sastra, telah menemukan titik temunya. Teks dan koteks pada kajian new historicism dilihat sebagai manifestasi sejarah yang sama. Hakikat objektif kenyataan menjadi relatif sebab dalam sudut pandang objektif, kenyataan tidak diberikan melainkan terusmenerus harus dibangun dengan konsekuensi tidak ada kenyataan yang benar-benar menjadi fakta dalam sebuah teks sejarah (Ratna, 2007).

\section{Kompleksitas Relasi Antara Pribumi dan Kolonial}

Hubungan antara Barat dan Timur merupakan hubungan yang bersifat dikotomis. Melalui dikotomi tersebut, Barat selalu diidentifikasikan sebagai ras yang unggul, kuat, dan cerdas. Di lain pihak, Timur distereotipkan sebagai bangsa yang lemah, bodoh, dan inferior. Tipe-tipe hubungan tersebut juga didukung oleh Said (2001) yang menyatakan hubungan antara Barat dan Timur adalah hubungan hierarki yang didominasi oleh kekuasaan dan hubungan berbagai derajat hegemoni yang kompleks.

Sebutir Peluru Saja yang berbicara bagaimana kompleksnya sejarah kolonialisme Belanda di Hindia. Cerpen itu menceritakan seorang schouten yang 
menghadapi dilema untuk menembak seorang perampok kondang bernama Kalasrengi atau membiarkannya untuk tetap hidup. Kalasrengi ketahuan merampok rumah Bendoro Saridin, seorang perantara pabrik gula. Dilema Tuan Skaut, panggilan akrab si schouten, tiba ketika Kalasrengi membeberkan alasannya menjadi garong, yaitu karena sawahnya direbut Bendoro Saridin untuk jadi lahan milik pabrik gula.

Ia masih termenung, mengamati asap yang mulai lenyap dari bedilnya. Apakah tadi terkejut lalu menarik pelatuk? Ataukah ia memang sengaja melakukan hal itu karena tak ingin dianggap sebagai pejabat bodoh yang begitu mudah ditipu oleh seorang garong? Entahlah. Yang jelas kini ia harus memutar otak, menyusun alasan 'pembunuhan' yang masuk akal untuk dibuat laporan. Teringat lagi ia perkataan kontrolir yang dahulu merekrutnya menjadi polisi: 'Kita adalah batu penjuru. Fondasi. Tempat bangunan peradaban Eropa yang megah diletakkan. Kita adalah teladan bagi sekalian orang Timur (Banu, 2019).

Kutipan di atas jelas menggambarkan bahwa adanya kompleksitas yang menguat dalam cerita seperti Kalasrengi ketahuan merampok dan meminta belas kasih kepada Tuan Skaut. Kalasrengi merampok karena sawahnya dirampas oleh Bendoro Saridin. Perantara pabrik gula itu mengambil sawah Kalasrengi demi kepentingan pabrik gula tempat ia bekerja. Pabrik gula ada untuk menggenjot produksi komoditas yang termasuk kebijakan tanam paksa. Kebijakan tersebut keluar dari pemerintahan yang memberi Tuan Skaut gaji yang sedikit. Tak ada konflik berlandaskan rasisme dalam cerita terebut. Kalasrengi ditindas Bendoro Saridin yang juga seorang pribumi. Bendoro Saridin yang telah makmur menjadi perantara pabrik gula meminta bantuan pada schouten yang seorang Belanda untuk menghabisi Kalasrengi.

Penggambaran tersebut sejalan dengan adanya hierarki dalam masyarakat, di mana masyarakat kaya melakukan ketidakadilan terhadap masyarakat yang miskin. Tidak hanya itu, penggambaran juga memperlihatkan bagaimana orang kolonialisme dalam pandangan Loomba (2003) yang menolak adanya sebuah proses identik melalui bagian dunia yang berbeda. Akan tetapi, di pihak lain, di mana pun kolonialisme tumbuh selalu terjadi hubungan-hubungan yang paling kompleks dan traumatis dalam sejarah manusia antara pribumi dengan pendatang baru.

Dalam Sebutir Peluru Saja, orang Belanda yang bertugas sebagai pengawas yang pada saat kejadian tersebut muncul dilema menentukan pilihan antara membela kelas atas atau bawah. Dikarenakan dukungan terlalu banyak pada pihak atas, pengawas tersebut teringat sebuah pernyataan bahwa bangsa Barat adalah teladan bangsa Timur, akhirnya ia segera menjatuhkan hukuman kepada kelas bawah berdasarkan dukungan terbanyak. Akibatnya, timbul pandangan egois dari bangsa Barat yang memosisikan peradaban Barat sebagai peradaban teladan bagi seluruh dunia dan Eropa adalah pusat dunia. Yang terbangun kemudian adalah peradaban Eropa merupakan suatu kreativitas brilian yang orisinal serta tidak mengenal batas ruang dan waktu (Kurniawan, 3013). 
Belenggu Emas masih berbicara mengenai kompleksitas, yakni dualisme sistem dalam masyarakat Minangkabau pada era kolonial. Berdasarkan tokoh Nellie, seorang wanita keturunan Belanda yang tinggal di Minang bersama suami Belandanya. Kenyataannya eksistensi wanita Minangkabau pada abad ke-20 masih terikat oleh belenggu peraturan yang patriarki (Yanti, 2017). Aturan mengikat tidak terhindarkan lagi, baik wanita pribumi maupun asing.

Kita ingin mengubah keadaan, mengubah mereka. Bukan berupa menjadi mereka. Orang putih harus menjadi teladan untuk segala hal. Termasuk berbusana. Orang di daerah ini mengenakan busana tradisional mereka masing-masing sebagai identitas. Kita, orang Eropa, tentu juga diharapkan mengenakan pakaian Eropa. Dengan demikian, keharmonisan terjaga (Banu, 2019).

Nellie yang telah berbaur dengan banyak wanita Minang mulai mengikuti memakai busana Minang, tetapi segera ditegur oleh suaminya yang sangat tegas terhadap peraturan bahwa telah ada sekatsekat pemisah antara bangsawan, orang Eropa, dan pribumi. Namun, berjalannya waktu proses kompleksitas relasi antara koloni dan pribumi tidak terhindarkan lagi. Kompleksitas relasi yang terjalin merupaka bentuk status sosial karena adanya interaksi budaya Timur dan Barat. Pada era kolonial Belanda terjadi relasi penjajah dan terjajah yang melahirkan perubahan, mulai dari budaya maupun sistem (Herdianingtyas, 2018).

Dalam perspektif tokoh Nellie, ia menginginkan kebebasan dalam kehidupannya yang tidak semata-mata menggantungkan nafkah pada suami atau sekadar menjadi perhiasan dalam rumah tangga. Nellie digambarkan sebagai sosok yang mencintai kebebasan, melihat bahwa perempuan dapat bekerja dalam melakukan berbagai hal yang dilakukan oleh kaum laki-laki. Kecintaannya adalah dapat menulis dan mengisi ruang pembaca dalam surat kabar. Meski ditentang oleh suaminya, kebebasannya tidak terhindarkan lagi sampai suatu ketika ia bertemu Roehana Koeddoes.

Kompleksitas relasi antara bangsa Belanda terhadap bangsa Indonesia tidak hanya berhubungan dengan eksploitasi sumber daya manusia dan alam, tetapi juga pada konstruksi budaya dan identitas. Penciptaan kategori ini merupakan bagian dari stereotipisasi "the Other" yang dioposisibinerkan dengan "the Self". Dengan demikian, para penjajah yang berupaya menumbuhkan citra superior mereka terhadap pribumi. Perbedaan identitas yang dicitrakan tidak hanya menyangkut warna kulit, tetapi juga budaya pembentuk identitas tersebut (Fajar, 2011).

Konsepsi kompleksitas realitas juga tergambarkan melalui Di Atas Kereta Angin, yang berbicara mengenai persamaan hak terhadap seluruh etnis yang tinggal di Hindia Belanda. Perubahan yang terjadi adalah sebuah inspirasi pribumi untuk mencari keadilan dan kesetaraan. Tokoh Kees dalam kisah Di Atas Kereta Angin digambarkan terbuka terhadap adanya perubahan yang terjadi atas persamaan berpakaian maupun transportasi, tetapi bertentangan dengan Jan yang menganggap hal itu menjatuhkan martabat priayi yang berada dalam kelas satu. 
Nah, mengapa bujangmu naik fiets dan memakai pantalon Eropa? Bukan kelompok kita saja yang tersengat melihat hal semacam itu. Tetapi juga para bangsawan bumiputra. Bagi mereka, pantalon dan sepatu adalah pembeda kedudukan antara priayi dan kawula. Jangan membuat mereka merasa terhina (Banu, 2019).

Kees memiliki bujang yang diperbolehkannya menggunakan fiets dan pantalon. Hal ini karena pada era tersebut, khususnya di wilayah Yogyakarta, Semarang, dan Surabaya, peraturan itu sudah tidak berlaku lagi. Jan dengan pemikiran masih kolot menganggap hal tersebut dapat mengakibatkan ketidakharmonisan antara penguasa Belanda, para priayi, dan pribumi kelas bawah. Kemunculan peralatan modern ke Hindia Belanda yang dibawa dari kebiasaan orang Belanda telah menjadi sebuah relasi budaya antar kedua bangsa (Hardiningtyas, 2018). Oleh karena itu, masuknya budaya Barat ke Hindia menjadikan masyarakat pribumi yang terjajah tidak menyianyiakan kesempatan ini untuk melakukan perlawanan dalam menyejajarkan persamaan hak sebagai sesama manusia yang tinggal di Indonesia.

Kompleksitas sistem kebudayaan telah menjalin relasi berarti bagi kedua bangsa. Pada awalnya pertentangan tidak terhindarkan lagi. Namun, seiring berjalannya waktu pihak pribumi bukanlah sebuah khayalan semata bagi koloni, melainkan suatu bagian dari pengalaman, kepribadian, peradaban, dan kebudayaan yang dianggap sebagai suatu kebalikan dari koloni bangsa Eropa (Said, 2001:2).
Melalui Indonesia Memanggil pun masih berkisar pada kompleksitas relasi pribumi dan koloni. Kisahnya berdekatan dengan kemerdekaan Indonesia jika dikaitkan dengan sejarah tertulis. Cerpen tersebut berbicara mengenai pemogokan besar-besaran para pekerja pelabuhan Australia. Pemogokan itu terjadi saat mereka mengetahui Belanda dengan seluruh senjatanya akan bertolak dari Australia untuk kembali menduduki Indonesia. Para pekerja pelabuhan ini kebanyakan ikut dalam partai komunis dan serikat buruh. Mereka melakukan mogok besar-besaran karena bersimpati pada kemerdekaan Indonesia atau lebih tepatnya pada para eks-Digulis.

Semua ini salah para Nippon berengsek itu. Ketika Hindia Timur jatuh ke tangan mereka tiga tahun lalu, nyaris seluruh warga Belanda mengungsi. Ada yang ke Amerika, Inggris. Tapi terbanyak ke sini. Ke Australia! (Banu, 2019).

Kutipan di atas jelas menggambarkan bahwa bangsa Jepang datang berusaha mengusir kolonial Belanda. Bahkan, dalam sejarah peristiwa besar itu benar terjadi pada era kolonialisasi. Pihak Belanda berspekulasi bahwa pengusiran koloninya akibat dari pribumi yang bekerja sama dengan Jepang untuk mengusir koloni Belanda dengan beragam cara hingga koloni Belanda melarikan diri.

Joris Ivens, seorang sineas asal Belanda, merekam sebuah kejadian untuk dijadikan film dokumenter berjudul Indonesia Calling. Peristiwa itu juga diabadikan dalam buku Black Armada karya Rupert Lockwood (Drew dan Angela, 2006:7). Melaluinya diberikan 
perspektif bahwa kebenaran kemerdekaan Indonesia berawal dukungan dari para liyan yang ikut berperan dalam kemerdekaan Indonesia. Kemerdekaan tidak diraih dengan hanya menggunakan tangan pribumi sendiri. Menurut sejarah, bukan perjuangan pribumi yang mengusir Belanda dari Hindia pada 1942, melainkan kedatangan penjajah baru bernama Jepang. Pelecut "api revolusi" para pribumi pun bukan orasi-orasi para tokoh pada waktu itu, melainkan para liyan yang berperan menjadi pendongkrak rangkaian kemerdekaan di negara-negara Asia-Afrika sehingga menyulut semangat bagi negaranegara lain untuk merdeka dari para kolonialis.

\section{KESIMPULAN}

Berdasarkan hasil penelitian dapat disimpulkan sebagai berikut. Pertama, kumcer Teh dan Pengkhianat karya Iksaka Banu jelas merepresentasikan tentang sejarah pada masa kolonial yang direkonstruksi kembali oleh pengarang sebagai bahan kritik. Kumcer ini menampilkan representasi bagaimana masyarakat menginginkan adanya persamaan hak antara Belanda dan pribumi. Tidak hanya pribumi yang diinterpretasikan menginginkan adanya persamaan hak, melainkan orang Belanda pun juga menginginkan adanya persamaan hak sehingga tidak ada perbedaan berarti sebagai sesama manusia yang tingga di suatu tempat yang sama. Kedua, penggunaan tokoh-tokoh yang sesuai dengan fakta sejarah dalam kumcer Teh dan Pengkhianat adalah Jan Pieterszoon Coen, Willemsz Verhoveff, Johannes Stertemius, Karaeng Pattingalloang, Dr. Jan Veldhart, Kelompok Cina Wanayasa,
Kalasrengi, Roehana Koeddoes, Abrahan de Withart, dan Joris Ivens. Ketiga, beberapa cerita dalam kumcer ini mengandung fakta sejarah sehingga dapat dijadikan salah satu alternatif dalam pembelajaran sastra dan sejarah, khususnya sejarah kolonial dan pascakolonial. Dengan demikian, kumcer ini tidak hanya ditulis berdasarkan imajinasi semata, melainkan juga berdasarkan fakta sejarah. Selain itu, penggunaan new historicism bermanfaat untuk melihat fakta yang terdapat di dalam kumcer Teh dan Pengkhianat.

\section{DAFTAR PUSTAKA}

Absiroh, U., I. Isjoni, dan B. Bunari. 2017. "Sejarah Pemahaman 350 Tahun Indonesia Dijajah Belanda". Jurnal Online Mahasiswa Fakultas Keguruan dan Ilmu Pendidikan 4(1):1-15. Retrieved from https://jom.unri.ac.id/index.php/JOM FKIP/article/view/12666/12308.

Al Kautsar, S. A. 2020. "Jejak Kolonial dalam Kumpulan Cerpen Teh dan Pengkhianat Karya Iksaka Banu". BAPALA 7(1):1-7. Retrieved from https://jurnalmahasiswa.unesa.ac.id/i ndex.php/bapala/article/view/33482/ 29967.

Ardhianti, M. 2016. "Kajian New Historicism Novel Hatta: Aku Datang Karena Sejarah Karya Sergius Sutanto". Jurnal Buana Bastra 3(1):1-10.

Artika, I. W. 2015. "Pengajaran Sastra dengan Teori New Historicm". Prasi 10(20):50-55.

Aromah, A. S. 2021. Hibriditas Tokoh Utama Belanda dalam Kumpulan Cerpen Teh dan Pengkhianat Karya 
Iksaka Banu. Universitas Airlangga.

Baha'uddin, B. 2016. "Dari Mantri Hingga

Dokter Jawa: Studi Kebijakan

Pemerintah Kolonial dalam

Penanganan Penyakit Cacar di Jawa

Abad XIX-XX". Humaniora

18(3):286-296. Retrieved from

https://jurnal.ugm.ac.id/jurnal-

humaniora/article/view/884/731.

Banu, I. 2019. Teh dan Pengkhianat.

Jakarta: Gramedia.

Barry, P. 2010. Beginning Theory:

Pengantar Komprehensif Teori Sastra

dan budaya. Terjemahan $\mathrm{H}$.

Widyawati dan E. Setyarini. Jakarta:

Jalasutra.

Baso, A. 2005. Islam Pascakolonial:

Perselingkuhan

Agama,

Kolonialisme, dan Liberalisme.

Bandung: Mizan.

Dewi, R. 2015. "Nilai-nilai Historis Novel

Babad Sriwijaya Karya Ferry Irawan

Am: Kajian Struktural Semiotik".

Bahtera: Jurnal Pendidikan Bahasa

dan Sastra 14(1):55-63.

Fathoni, M. 2013. "Kritik Sastra Puitika

Kultural Stephen Greenblatt: Metode

dan Praktik Analisis". Poetika

1(2):151-168.

https://doi.org/10.22146/poetika.v1i2

.10411

Hardiningtyas, P. R. 2018. "Mimikri,

Mockery, dan Resistansi Gaya

Hidup Pribumi Terhadap Budaya

Kolonial Belanda dalam Tetralogi

Pulau Buru". Metasastra Jurnal

Penelitian Sastra 11(1):91-112.

Haryadi, A. D. 2013. Obyektivitas Ilmu

Sejarah Ditinjau dari Aksiologi Ilmu

Hugh Lacey. Universitas Gadjah Mada.

Ikbar, A. dan Andalas, E. F. 2019. Dampak
Psikologis Kolonialisme Barat Terhadap Masyarakat Pribumi dalam Kumpulan Cerpen Aloer-Aloer Merah Karya Ardi Wina Saputra. Deiksis: Jurnal Pendidikan Bahasa dan Sastra Indonesia 6(2): 1 . https://doi.org/10.33603/dj.v6i2.1844

Indriani, W. J. 2014. Representasi Otoritarianisme dalam Film Inglourious Basterds Karya Quentin Tarantino. Bandung: Universitas Komputer Indonesia.

Kirom, S. 2020. "Memutus Kuasa Postkolonial di Indonesia dalam Perspektif Filsafat Sejarah Kritis". KAMBOTI: Jurnal Sosial dan Humaniora 1(1):13-20.

Loomba, A. 2003. Kolonialisme: Pascakolonialisme. Yogyakarta: Bentang.

Maharani, P., D. Suhendi, dan A. Ansori. 2020. Hibdriditas dan Ambivalensi dalam Kumpulan Cerpen Semua untuk Hindia dan Teh dan Pengkhianatan Karya Iksaka Banu: Kajian Sastra Postkolonialisme dan Implikasinya dalam Pembelajaran Sastra. Palembang: Universitas Sriwijaya.

Mandiri, S. S. 2017. Potret Kekejaman Kaum Feodal Terhadap Pribumi Jawa dalam Novel Gadis Pantai Karya Pramoedya Ananta Toer. Jurnal Bahasa dan Sastra Indonesia 6(6):770-785.

Multatuli, M. 2016. Max Havelaar. Bandung: Mizan.

Oktiva, T., dan O. R. Syamsudin. 2021. Unsur-unsur Sejarah dan Nilai Pendidikan Karakter dalam Kumpulan Cerpen Teh dan Pengkhianat Karya Iksaka Banu. 
Diskursus: Jurnal Pendidikan Bahasa Indonesia 4(1):87-97.

Purnamasari, B. W. A. 2018. Novel Arok Dedes Karya Pramoedya Ananta Toer dengan Kajian New Historicism Stephan Greenblatt. Jurnal Bapala 5(2): 1-10.

Rahayu, L. M. 2017. Identitas Keindonesiaan dalam Drama Indonesia Tahun 70-an:

Sebuah Pembacaan New Historicism. Prosiding Seminar Nasional, PBSI FKIP Universitas Jember.

Ratna, N. K. 2007. Sastra dan Cultural Studies, Representasi Fiksi dan Fakta. Yogyakarta: Pustaka Pelajar. Rusdian. 2017. Mimikri dan Resistensi Pribumi Terhadap Kolonialisme dalam Novel Jejak Langkah Karya Pramoedya Ananta Toer: Tinjauan Poskolonial. Caraka 4(1):33-58.

Said, E. W. 2001. Orientalisme. Bandung: Penerbit Pustaka.

Sahliyah, C. 2017. Kajian New Historicism pada Novel Kubah Karya Ahmad Tohari. Jurnal Pendidikan Bahasa dan Sastra 17(1):108-116.

Sari, N. 2021. Resistensi Ideologis dalam Antologi Cerpen Teh dan Pengkhianat Karya Iksaka Banu: Kajian pascakolonial. Jambi: Universitas Jambi.

Somantri, G. R. 2005. Memahami Metode Kualitatif. Makara, Sosial Humaniora 9(2):57-65.

Sugiarti, E. F. Andalas, dan A. Setiawan. 2020. Desain Penelitian Kualitatif Sastra. Malang: UMM Press.

Sugiono. 2013. Metode Penelitian Pendidikan:Pendekatan Kuantitatif,
Kualitatif, dan $R \& D$. Bandung: Alfabeta

Teng, M. B. A. 2016. Orientalis dan Orientalisme dalam Perspektif Sejarah. Jurnal Ilmu Budaya 4(1):48-63.

Wellek, R., dan A. Warren. 2014. Teori Kesusastraan. Jakarta: Gramedia Pustaka Utama.

Wibowo, E. 2018. "Kajian Nilai-Nilai Historisme dalam Novel Anomie Karya Rilda A. Oe. Taneko". Balai Banda Aceh 7(1):91-100.

Wibisono, J. A., J. D. W. Tjahjo, dan M. Wahjudianta. 2017. "Representasi Orientalisme dalam Film The Great Wall". Scriptura 7(1), 36-45.

Wisnuwardana, I. G. W. 2016. Kebijakan Pemerintah Kolonial dalam Penanganan Penyakit Cacar di Jawa Abad XIX-XX. Social Studies 4(1):1-15.

Yanti, R. M. 2017. "Lahirnya Pergerakan Perempuan Minangkabau pada Awal Abad XX". Kafaah Journal 7(2):147-158.

Yasa, I. N. 2013. "Orientalisme, Perbudakan, dan Resistensi Pribumi Terhadap Kolonial dalam Novelnovel Terbitan Balai Pustaka". Jurnal Ilmu Sosial dan Humaniora 2(2): 249-256.

https://doi.org/http://dx.doi.org/10.23 887/jish-undiksha.v2i2.2179.

Yunan, M. D. 2015. Fenomena Konflik Etnis di Kalimantan Barat Sebagai Inspirasi Penciptaan Naskah Drama "Junjung Sumpah". Institut Seni Yogyakarta. 